\title{
Nada Act 1 : une architecture à cordes
}

\author{
Marie-Hélène Lemaire, Fondation PHI pour l'art contemporain \\ mhlemaire@phi.ca
}

\begin{abstract}
$N$
ada Act 1 (2016) est une œuvre de l'artiste slovène Jasmina Cibic. Sous la forme d'une installation filmique, elle porte sur le pavillon national que l'exYougoslavie a présenté à l'Exposition universelle de Bruxelles en 1958, tel qu'imaginé à l'origine par l'architecte croate Vjenceslav Richter. Elle est composée d'une maquette architecturale avec un mât central et une structure suspendue, réinterprétée par l'artiste en tant qu'instrument à cordes aux mains de la violoniste Dejana Sekulic. Un film projeté au mur nous permet de voir et d'entendre Sekulic alors qu'elle joue de cette maquette. Nada Act l (2016) a été présentée dans l'exposition individuelle de Jasmina Cibic, Everything That You Desire and Nothing That You Fear, qui a eu lieu à la Fondation PHI pour l'art contemporain du 25 octobre 2018 au 3 mars 2019.
\end{abstract}

Mon article Les concepts en mouvement : une méthode basée sur la poésie pour la visite de groupe dans l'exposition d'art contemporain porte sur cette exposition. Lorsque je mets en jeu ma méthodologie des concepts en mouvement, je me sers des mots dans leurs qualités matérielles - leurs textures, résonances, tonalités, rythmes et musicalité - afin de faire émerger l'affect et la poésie des œuvres d'art. Je vois dans l'approche de la violoniste Sekulic une parenté avec ma méthode, car en jouant du pavillon national comme s'il était un instrument de musique, elle dégage de l'architecture une dimension sonore vibratile et résonante qui serait autrement restée silencieuse.

\section{Figure 1}

Nada Act 1 (Cibic, 2016).

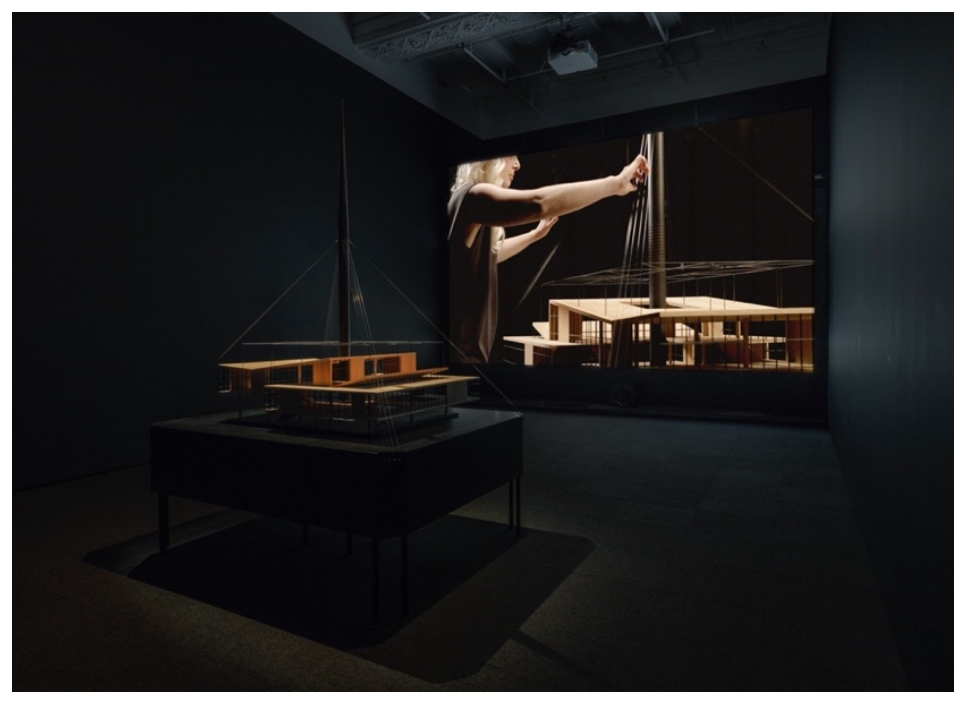

Revue Canadienne d'éducation artistique, 48(1) 


\section{Références}

Cibic, J. (2016). Nada : Act 1 [Installation et Vidéo]. (Photo : R. M.

Tremblay). Everything That You Desire and Nothing That You Fear, 20182019. Fondation PHI pour l'art contemporain. 


\title{
English Translation
}

\section{Nada Act 1: A String Architecture}

\author{
Marie-Hélène Lemaire, PHI Foundation for Contemporary Art \\ mhlemaire@phi.ca
}

ada Act 1 (2016) is a filmic installation by Slovenian artist Jasmina Cibic that
focuses on Ex-Yugoslavia's national pavilion presented at the Universal
Exhibition in Brussels in 1958, as it was originally imagined by Croatian architect Vjenceslav Richter. The installation comprises an architectural model, which is equipped with a central mast and a suspended structure, as well as a projected film that shows violinist Dejana Sekulic playing the Yusgoslav pavilion as if it were a string instrument. Nada Act 1 (2016) was part of Jasmina Cibic's solo exhibition Everything That You Desire and Nothing That You Fear, shown at the PHI Foundation for Contemporary Art, between October 25 ${ }^{\text {th }}, 2018$, and March $3^{\text {rd }}, 2019$.

I wrote about this exhibition in my article Les concepts en mouvement : une méthode basée sur la poésie pour la visite de groupe dans l'exposition d'art contemporain [Concepts in Movement: A poetry-based method for group visits within contemporary art exhibitions]. Whenever I bring into play my Concepts in Movement methodology, I use the material qualities of words, such as texture, resonance, tonality, rhythm, and musicality, to reveal the affect and poetry of works of art. The approach chosen by violinist Sekulic appears very close to my methodology, since by playing the national pavilion as if it were a musical instrument, she draws a vibratile and resounding sonic dimension from the architecture that would have otherwise remained silent.

\section{Figure 1}

Nada Act 1 (Cibic, 2016). 


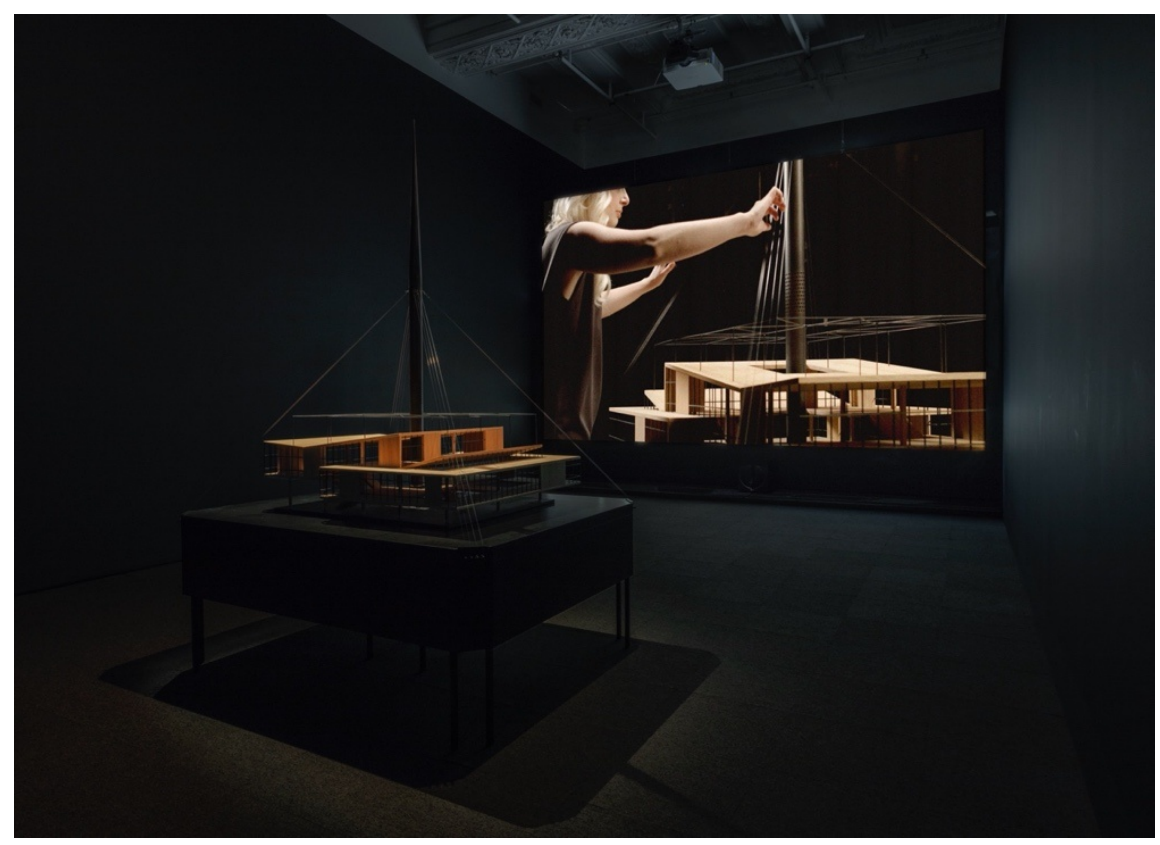

\section{References}

Cibic, J. (2016). Nada : Act 1 [Installation and Video]. (Photograph: R. M. Tremblay). Everything That You Desire and Nothing That You Fear, 20182019. Fondation PHI pour l'art contemporain. 